\title{
Marketing Management Trends in Tourism and Hospitality Industry: Facing the 21st Century Environment
}

\author{
Nuno Gustavo ${ }^{1}$ \\ ${ }^{1}$ Estoril Higher Institute for Tourism and Hotel Studies, Estoril, Portugal \\ Correspondence: Nuno Gustavo, Estoril Higher Institute for Tourism and Hotel Studies, Av. Condes de \\ Barcelona, 2769-510 Estoril, Portugal. Tel: 351-2-1004-0700. E-mail: nuno.gustavo@eshte.pt
}

\author{
Received: February 14, 2013 Accepted: March 5, 2013 Online Published: April 15, 2013 \\ doi:10.5539/ijms.v5n3p13 URL: http://dx.doi.org/10.5539/ijms.v5n3p13
}

\begin{abstract}
The new dynamics of the twenty-first century led to a new competitive environment in the field of tourism and hospitality business. This scenario is driving the industry companies to adopt new strategic marketing options and operational marketing processes.

At first, as introduction, the paper identifies and reflects, in general, the new and main principles of the macro environment of tourism businesses, taking a STEEP analysis matrix as a reference. After describing the above scenario, the paper focuses on the major changes on the level of the tourism and hospitality micro environment, outlining the main changes and trends in the demand and supply side. Finally, the paper presents a set of reflections and trends on the strategic and operational marketing management of tourism and hospitality businesses, expression of the new (macro and micro) environment. In order to support the trends suggested, different case studies based on international hospitality companies are presented and analyzed.
\end{abstract}

Keywords: hospitality, trends, strategic marketing, operational marketing

\section{Introduction}

The basis for this reflection and its consequent questioning lies on the unavoidable structural changes which characterize the awakening of the $21^{\text {st }}$ century and which are determining factors for the mutation of the macro environment of societies in general and tourism business in particular (Knowles, et al., 2004; Holjevac, 2003). Generally speaking it is possible to state that we are facing a new set of transformations which have made present everyday life more global, uncertain and dynamic (Tribe, 2010).

Consequently we notice the presence of a set of profound transformations in the socio-cultural matrix of today's societies, especially Western societies, where a new socio-demographic profile stands out. This profile is characterized by a new tendency towards the decrease of birth rates, the increase of average life expectancy, changes in the concept of family, a growing urbanization and a unique and simultaneous coexistence of four different generations (Traditionalists, Baby Boomers, Generations Xers, Millenials). These generations have distinctive socio-cultural characteristics due to the structural differences which have shaped their everyday life and arose unique challenges in what concerns communication and interpersonal relationships (Lancaster \& Stillman, 2002). Millenials, also known as Generation Y, are the clients of the future, because "... Millennials access digital media on daily basis and have the ability to communicate with and purchase from suppliers anywhere in the world." (Mangold \& Smith, 2012:141), and so it is vital to acknowledge the importance of such profile.

The exponential development and increased dependence of technology in the context of the present society place it as the central paradigm of the social and economic development and thus changing the limits of ability and means of production. Considering its impact on the lifestyle and communication of the population, the internet is probably one of the most important elements of this revolution. It has deeply changed the notion of time, shortening reality and establishing new lines of spatial, time and management organization (Abrate et al., 2012).

On the economic level, there is the emergence of new markets, especially the binomial resulting from the interaction between emerging and developed economies (Yeoman et al., 2012). This emergence is the result of the extension and intensification of globalization, which for the first time puts the concept of market, and consequently business competitiveness, on a universal level. The rise of new trade blocks such as BRIC (Brazil, 
Russia, India and China) tends to alter the natural balance of the markets in which "new consumers Markets will contribute to transition economies (Central and Eastern Europe) and in developing economies" (Asia and South Asia) (Yeoman, 2008:25).

On the other hand, the financial markets crisis, namely of the subprime and sovereign debt, limited not just the immediate prospect of public and private investments, but jeopardized the entire paradigm of economic development, thus creating a climate of unparallel uncertainty and insecurity, especially within developed economies.

Regarding the environment, sustainability is represented in the "green argument" as the vital assumption of the model of sustainable development and therefore tends to be a requirement, rather than an optional or differentiating matter. The evidence of environmental limitations, namely the increasing impact of climate change, has turned this matter into a fundamental issue in the agenda for the $21^{\text {st }}$ century, thus forcing social awareness and demanding new behaviors, attitudes and actions towards the environment (Kang et al., 2012).

On the political level, the terrorism portrayed in the events of the $9 / 11$ has become a unavoidable reality and the feelings of insecurity and volatility have altered people's lifestyle and encourage short-term perspectives rather than the traditional long-term perspective (Taylor \& Chesworth, 2005). There is also the distinctive rising of neoliberal ideals which lead to an increasingly more open market. The private market tends to develop thanks to a growing number of companies that, facing no barriers and resulting from such liberalization, tend to compete in different markets on a global level.

The progress in the neoliberal philosophies is also seen in other aspects such as the significant decrease in the state's actions regarding the "Welfare State" and consequent cuttings in social benefits like paid holidays and Social Security. The "flexibilization" of different legal frameworks, like the labor market, is also noteworthy.

\section{The New Micro Environment of Tourism and Hospitality Industry}

\subsection{Tendencies of the Tourism Demand}

Throughout times tourism market has registered transversal characteristics like the increase of its supply and demand, which is something evident when we analyze international tourism demand data.

According to the United Nation World Tourism Organization (UNWTO) this demand was around 25 million in 1950 and today it has reached 1.000 million tourists (UNWTO, 2013). On the other hand, also according to the UNWTO forecast for 2030, it is expected that international tourism increases in the next 10 years as much as in the period between 1950-2010 and, therefore, we could face a tourism demand of about 1.8 million tourists in 2030 (UNWTO, 2011).

This is clearly an exponential increase of tourism demand resulting especially from the increasing development of the world economy, in particular of emerging economies like Brazil, India and Dubai, and political openness of countries such as China and Russia. This scenario of increased globalization of the tourism activity is clearly stimulated by the intense development of technology and reflects on the growing accessibility of new destinations especially due to developments in air transport.

However it should be noted that Europe still remains the major destination of international tourism and the greatest producer and receptor of tourists, despite the percentage decrease in worldwide tourism activity. Western European countries, as well as Middle East and Asia, are major emerging destinations. And this makes competition among destinations a vital variable of the tourism market.

Given this reality tourism demand is likely to become disperse. The five main tourism destinations regarding international tourists arrivals held $71 \%$ of the market in 1950 whereas today (2009) this number decreased to $31 \%$. In contrast destinations other than those on the Top 15 represent already $44 \%$ (and just $3 \%$ in 1950) (see Table 1). 
Table 1. Evolution of international tourism demand by tourism destination market share 1950-2010

\begin{tabular}{|c|c|c|c|c|c|c|c|c|}
\hline Rank & 1950 & Share & 1970 & Share & 1990 & Share & 2010 & Share \\
\hline 1 & $\begin{array}{l}\text { United } \\
\text { States }\end{array}$ & \multirow{5}{*}{$71 \%$} & Italy & \multirow{5}{*}{$43 \%$} & France & \multirow{5}{*}{$38 \%$} & France & \multirow{5}{*}{$31 \%$} \\
\hline 2 & Canada & & Canada & & United States & & United & \\
\hline 3 & Italy & & France & & Spain & & $\begin{array}{l}\text { States } \\
\text { China }\end{array}$ & \\
\hline 4 & France & & Spain & & Italy & & Spain & \\
\hline 5 & Switzerland & & United States & & Hungary & & Italy & \\
\hline 6 & Ireland & \multirow{5}{*}{$17 \%$} & Austria & \multirow{5}{*}{$22 \%$} & Austria & \multirow{5}{*}{$19 \%$} & $\begin{array}{l}\text { United } \\
\text { Kingdom }\end{array}$ & \multirow{5}{*}{$14 \%$} \\
\hline 7 & Austria & & Germany & & $\begin{array}{l}\text { United } \\
\text { Kingdom }\end{array}$ & & Turkey & \\
\hline 8 & Spain & & Switzerland & & Mexico & & Germany & \\
\hline 9 & Germany & & Yugoslavia & & Germany & & Malaysia & \\
\hline 10 & $\begin{array}{l}\text { United } \\
\text { Kingdom }\end{array}$ & & $\begin{array}{l}\text { United } \\
\text { Kingdom }\end{array}$ & & Canada & & Mexico & \\
\hline 11 & Norway & \multirow{5}{*}{$9 \%$} & Hungary & \multirow{5}{*}{$10 \%$} & Switzerland & \multirow{5}{*}{$10 \%$} & Austria & \multirow{5}{*}{$10 \%$} \\
\hline 12 & Argentina & & Czechoslovakia & & Greece & & Ukraine & \\
\hline 13 & Mexico & & Belgium & & Portugal & & Hong Kong & \\
\hline 14 & Netherlands & & Bulgaria & & Malaysia & & $\begin{array}{l}\text { (China) } \\
\text { Russia } \\
\text { Federation }\end{array}$ & \\
\hline 15 & Denmark & & Romania & & Croatia & & Canada & \\
\hline Total & $\begin{array}{l}\text { Others } \\
\mathbf{2 5} \text { million }\end{array}$ & $3 \%$ & $\begin{array}{l}\text { Others } \\
\mathbf{1 6 6} \text { million }\end{array}$ & $25 \%$ & $\begin{array}{l}\text { Others } \\
\mathbf{4 4 1} \text { million }\end{array}$ & $33 \%$ & $\begin{array}{l}\text { Others } \\
940 \text { million }\end{array}$ & $45 \%$ \\
\hline
\end{tabular}

Source: UNWTO (several years) organized by the Author

\subsection{Tendencies of Tourism Supply}

Given this growing globalization of tourism as a consequence of the aforementioned circumstances, tourism supply has evolved in an attempt to answer today's challenges.

Regarding aviation, development and consolidation of airline alliances (such as Star Alliance, One World, Sky Team) alongside the technological development of flight equipments, reflect the need for an increasingly global and efficient air transport. The dispersion of the tourism activity on a worldwide level has exceeded the operating limits of traditional international legacy companies and forced them to develop cooperation and integration processes. From simple interline agreements to code-share, this reality has evolved to the currently dominant model of airline companies integration: alliances.

However air transport market has already shown signs that this is not the end of this integration process, as the recent mergers and acquisitions between airline companies like KLM-Air France, British Airways-Iberia and Continental-United have proven. Moreover, the dispersion of tourism activity towards new destinations, namely the Middle East, has fostered the development of air transport in this area (Emirates, Qatar Air, Ethiad, etc.), a fact that is proven by the number of flight equipments scheduled to be delivered until 2013. As result, "the air transport's centre of gravity is moving eastwards" (Airbus, 2012:41). The increasing relevance of airlines in the Middle East comes from the geographical positioning of their hubs, and especially relevant in long haul flights based in the hub \& spoke model, as well as the important economic and financial advantages these companies have due to their shareholding structures (with available capital to invest) and access to strategic natural resources (low cost fuels, which represent $1 / 3$ of the entire cost structure of an airline) (Doganis, 2001).

Alongside the cooperation of the legacy companies we have also witnessed the development of the low-cost market that has proven itself to be an alternative supply especially in medium haul flights and which has translated into an increase of the business competitiveness and decrease of airline companies' profits (especially legacy). 
Due to this particular circumstance as well as the current business context, airlines are presently facing a challenging scenario that is translated in a return on capital insufficient to afford the cost of capital (IATA, 2010).

However the phenomena of the concentration of the tourism supply associated to a philosophy of worldwide service is not limited only to the airline business. In the hotel business we also witness the growth and development of huge international hotel chains like Accor, Starwood, Marriott or Intercontinental. Such growth is both quantitative and qualitative. If on the one hand the hotel chains have proven their commitment to the development of a worldwide supply (with recent and frequent openings in emerging destinations like the Middle East), on the other they have also developed their brand portfolio aiming even more to an increasingly specialized demand. The Accor group, for example, has now four different levels that vary from budget to luxury and upscale (ex: Fórmula 1 -1 star-, Ibis -2 star-, Mercure -3 star, Novotel -4 star- and Sofitel -5 star) (Accor, 2011) and has recently launched the brand hotelF1, slightly different from the more traditional Formulal because it is not just a budget hotel, but a design budget hotel.

In travel agencies we notice a similar phenomena. Thomas Cook and TUI, which clearly dominate the European market, have presently a business portfolio of over 300 brands. Its scope has widened and they are now working far beyond their initial purpose of intermediaries and wholesale and retail businesses in the tourism activity.

This is also noteworthy in other tourism sectors such as the rent-a-car, like Avis, Sixt, Europcar or Hertz, and the cruise ships market owned by two major companies: Carnival Corporation and Royal Caribbean. Their wide brand portfolio is the result of the evolution of the cruise market through various mergers and acquisitions. Carnival Corporation owns brands such as Carnival, Princess Cruises, Costa, P\&O, Holland America Line and Cunard. Such a universe of brands and services and wide range of concepts ensures the parent company a global positioning.

In conclusion, it seems evident that in a context of growing globalization, tourism supply business has evolved from a model of monopoly to one of oligopoly, but guaranteeing at the same time the necessary specialization of the supply in a wide and unique portfolio of products and services - total global strategy (Yip, 1992) - where brands are the structuring and vital element.

\section{New Marketing Strategies and Business Models}

Tourism and hospitality companies today face a scenario of exceptional uncertainty and change with a new economic and social growth henceforth marked by a new geopolitical and economic balance with new poles of development (Yeoman, 2008).

In this unique setting, tourism reinforces its significance as an economic and social activity, has it is proven by the worldwide increase of an ever-more global and heterogeneous tourism demand.

Given this reality and bearing in mind the above mentioned fundamental premises, the main "players" of the tourism business have opted for a new set of strategic options that guarantee their competitiveness in this new transnational environment.

Considering the market pressure, whether through its rapid development especially in the context of emerging economies, or by the restructuration in the context of the developed economies due to the excess of supply, the major "players" of the tourism sector have opted for the development of business through asset-light solutions (management contracts and franchising) and strategic partnerships as well as mergers and acquisitions, at the expense of other solutions sustained in organic development. This reality has contributed for the increase and growth of (big) hotel chains and brands instead of the traditional model of independent properties (O'Neil \& Carlbäck, 2011).

The latter, which is particularly relevant in business contexts where tourism companies show high and significant levels of growth, has a set of advantages namely on what concerns the rapidness of the developing process of the business and/or elimination of potential supply competitors.

One of the examples of this is the recent joint-venture of the Spanish hotel chain AC Hotels with the American Marriott (according to their strategic plan for Europe 2010-2015, Marriott intends to double its supply - 40.000 to 80.000 rooms - in a five year period) (Marriott International Inc., 2012). On the one hand, the hotel universe became more concentrated regarding its business structure, but on the other a new brand was born - AC Hotel by Marriott - thus maintaining the brand universe. However, this strategic option of growth through the concentration of the market is clearly sustained by the principles of the scope, scale and knowledge economies and has been used in a meticulous way since the businesses involved in such processes have respected and promoted the development of their brand portfolio (Canina et al., 2010). 
This trend in the development of the tourism market, particularly evident in the context of the developed economies as mentioned before, was recently proposed with the matrix - Otus Theory - and proven in the particular hotel context:

"The theory predicts that within an economy, the greater the contribution of service businesses to gross domestic product (GDP) then the greater the domestic business demand for hotels, the greater the domestic leisure demand for hotels, the greater the supply of hotels, the greater the concentration of hotels in brands and the greater the diversity of branded hotels" (Slattery, 2009:113).

This demonstration is based on two of the most relevant world economies which are a reference on tourism: the United States and the United Kingdom. It is noteworthy, that the development of the hotel and hotel chains market, as well as the associated brands, of these two countries have registered a significant growth in contrast to a relatively stagnant independent hotel supply level - stand alone (Slattery, 2009).

This reality is also particularly noticeable in the specific context of air transport with a predominant alliance model (see Table 2).

Table 2. Major air transport alliances in figures

\begin{tabular}{|c|c|c|c|}
\hline Alliance & $\begin{array}{l}\text { Star Alliance } \\
\text { (2011) (Note 1) }\end{array}$ & $\begin{array}{l}\text { One World } \\
\text { (2011) (Note 2) }\end{array}$ & $\begin{array}{l}\text { Skyteam (2011) } \\
\text { (Note 3) }\end{array}$ \\
\hline Foundation Date & 1997 & 1999 & 2000 \\
\hline Members & 27 & 12 & 15 \\
\hline Countries served by the network & 185 & 147 & 173 \\
\hline Lounges & $>990$ & 506 & 490 \\
\hline Daily Departures & 21.230 & N/D & 14.520 \\
\hline Passengers/year (thousand) & 648.54 & 303.7 & 487 \\
\hline Employees & 402.979 & 277.422 & 399.496 \\
\hline Fleet & 4.335 & 2.315 & 2431 \\
\hline Available Seat Kilometers (bil) (Note 4) & $1280.5(31.7 \%)$ & $891.1(22.0 \%)$ & $1042.9(25.8 \%)$ \\
\hline Operating Revenue (bil) $)^{5}$ & $127.2(30.2 \%)$ & $86.8(20.6 \%)$ & $97.7(23.2 \%)$ \\
\hline Global Passengers Shares (mil) $)^{5}$ & $459.4(29.8 \%)$ & $285.5(18.5 \%)$ & $357.6(24.3 \%)$ \\
\hline Revenue Passenger Kilometers (bil) ${ }^{5}$ & $980.8(30.8 \%)$ & $684.8(21.5 \%)$ & $818.9(25.7 \%)$ \\
\hline $\begin{array}{l}\text { Weighted average of indicators of } \\
\text { worldwide market share }\end{array}$ & $30.6 \%$ & $20.7 \%$ & $24.8 \%$ \\
\hline
\end{tabular}

Source: The Author

However this alliance model tends to disappear given the new and rather more integrated business models that occur with mergers and acquisitions.

Mergers and acquisitions are able to guarantee a quick growth of the companies as well as a quick process of restructure and integration on organizational and operation levels. This strategic option also ensures a greater negotiating power to these new macrostructures, alongside the consolidation of the supply and the elimination of competitors which are both undeniably important in the present context of economic crisis and uncertainty in economic and financial markets.

On the one hand it is necessary to consolidate and eliminate excessive supply, and on the other, given the expansion to new markets that lack investment and development, entrepreneur dimension is vital in obtaining these resources. However this strategic option does not once again ignore the necessary specialization of the market. For instance, in the cases of the KLM-Air France and Iberia-BA (IAG) mergers both brands were kept maintaining their independency despite the fact that four companies were turned into 2 .

If on the one side this concentration of the market is increasingly more evident despite its successive specialization emphasized on brands, on the other side we still witness a universe of supply with independent and dissociated characteristics from the major economic groups (Holjevac, 2003).

In fact this seems to be the binomial of business models in the tourism sector in the $21^{\text {st }}$ century: international macrostructures sustained in a relatively standardized product and other minor, autonomous and independent companies which resort to alternative business models. 
We can observe this in the airline business with the growth of the low cost model, and in the hotel business where the new operating strategies online allow stand alone hotel units to face competition and ensure their specialization and differentiation. Online distribution is also an emerging reality evidenced by the sort of services provided by Room Trade (HOTUSA) that offers its clients (hotels) access to over 100 IDS's (internet distribution system) channels through a single contract. Regarding the IDS Booking.com (www.booking.com) has a unique position as the european market leader. Through this IDS an independent hotel or one belonging to a small national level hotel chain will be able to gain fame and credibility among consumers. By joining this platform/brand the hotel will benefit from the brand capital and especially from the quality warranty these IDS hold among consumers on a global level. Thus stand alone hotels are able to position themselves (at a low cost and variables depending on the bookings they get) in a worldwide market dominated by major international hotel chains and brands and ensure the necessary recognition in a global competition context.

To overcome this branding drawback when competing with international hotel chains the small independent hotel can also be part of marketing consortiums such as the Small Luxury Hotels. These solutions give independent hotels the chance of belonging to an international network brand and its own booking mechanisms at a low cost, ensuring at the same time the necessary recognition of reputation the consumer needs to feel.

Moreover the inherent benefits of an online economy are not limited just to communication. It is also possible to use different solutions of renting and/or outsourcing for housekeeping, for example. This ensures the reduction of investment and fixed costs, two important issues on which major international hotel groups clearly have an advantage due to the nature and dimension of their structures.

In the context of airline business, the monopoly circumstances caused by airline alliances as a consequence of the succeeding liberalization of markets and privatization of many of the legacy companies have shaped today's paradigm of the market.

Under the premise if an intercontinental service and based in the model of hub\& spoke, legacy companies have used alliances to take advantage of the benefits of the scale, scope and density economies, cost reduction, elimination of legal barriers and creation of additional barriers to new competitors through their negotiating power (Doganis, 2001).

“... there can be little doubt that airline executives see alliances, especially when they involve code-sharing and capacity rationalisation, as a way of reducing or limiting competition." (Doganis, 2001:79)

The paradigm of airline alliances was sustained in the market liberalization process initiated in the eighties and strengthened throughout the nineties, creating the necessary conditions for the successive integration and monopoly in this market. We are currently witnessing the beginning of the last stage of this process of integration and consolidation: the merger and acquisition of airlines companies (like British Airways/Iberia and United/Continental).

As an alternative against all the barriers and monopoly resulting from these alliances, low cost companies have developed an intra-regional business model based on assumptions and different concepts of services which are marked by an unbundled service and a simple point-to-point operation. Yet the difference between these two business models lies also on its operational and strategic management, quite different from legacy companies: emphasizing on downsizing, informality and versatility.

This new flying and management philosophy has considerably changed the dominant position of strategic alliances because it has altered the density balance of intra-regional city pairs and forced many legacy companies to initiate/accelerate their merging and acquisition processes in order to eliminate over supply and increase their competitiveness and negotiating power.

"...[T] he rationale for large networks has been found in economies of scope, density and scale, while the volume synergy of expanding airline networks has been found to be exponential" (Weber \& Dinwoodie, 2000:51).

This reality and the consequent potential development of the budget market is quite important and can also be extended to other tourism sectors like the hotel business.

\section{New Paradigms of the Operational Marketing Management: Marketing 3.0 \& Marketing Mix 4e's}

Given the main strategic marketing options mentioned above, the premises of operational marketing management also tend to change. As an alternative to the Marketing 2.0 paradigm and the traditional 4p's of the marketing mix (price, product, placement and promotion), tourism businesses tend to develop new operational management models reinvented now under the Marketing 3.0 paradigm and 4e's mix (emotion, exclusivity, 
engagement and experience) where brand management and online situation have a significant role (Kotler et al., 2010; Lusensky, 2011).

Marketing 3.0 lifts the concept of marketing into the arena of human aspirations, values, and spirit. Marketing 3.0 believes that consumers are complete human beings whose other needs and hopes should never be neglected. Therefore, Marketing 3.0 complements emotional marketing with human spirit marketing. In times of global economic crisis, Marketing 3.0 gains more relevance to the lives of the consumers as they are impacted more by rapid social, social, economic, and environmental change (Kotler et al., 2010:4).

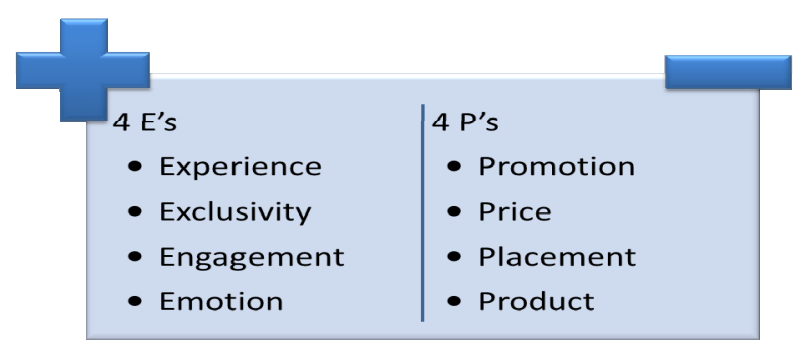

Figure 1. Marketing mix: from 4p's to 4 e's

Source: The Author

\subsection{From Promotion to Emotion: Brands \& More Brands}

In a tourism market that tends more and more towards the characteristics of oligopoly, and alongside a tourism demand which is increasingly more comprehensive, diverse and global, brands tend to be a vital management element given that they give companies the necessary tools to cover their growing global business spectrum (concerning markets and products) and at the same time guarantee the means for the segmentation of its products and markets in an increasingly heterogeneous and global demand.

In this scenario, brands are much more than a simple link in a business relationship between consumers and companies, and become an emotional asset. For this reason, tourism companies tend to ground their brands in a set of human and spiritual values and to create bonds and communities among its consumers. For instance, several companies have already created innumerous programs of responsibility and environmental awareness, like Starwood:

"We, at Starwood Hotels \& Resorts Worldwide, Inc., believe that economic growth and the well-being of society are inextricably tied to the health of the environment. Accordingly, we embrace our responsibility for environmental stewardship and are committed to integrating leading environmental practices and sustainability principles into our core business strategy" (in www.starwood.com).

Facing a society increasingly sensitive to environmental issues and clients who are more emotional and concerned about values and global and personal well-being, the purpose of these companies is not only to occupy such place in the mind of the consumer but also to establish an emotional and permanent relationship with him/her, thus sharing common ideals which are determining factors at the moment of purchasing a service, i.e. in the context of the business relationship.

Nonetheless this affective dimension of social well-being goes beyond environmental issues. The development of social responsibility programs tends to become a common practice among tourism companies. Like tourism activities, these projects have no boundaries nor nationalities and operate on an international level. For instance, Emirates Airlines has created a social responsibility campaign through the Emirates Airline Foundation aiming to help the children of Bangladesh, India, Sri Lanka and Kenya.

“(...) The Emirates Airline Foundation provides humanitarian, philanthropic aid and services for children in need. The Foundation aims to improve the quality of life for children, regardless of geographical, political, or religious boundaries, and to help them maintain and improve their human dignity" (in www.emirates.com).

These values tend to become the values of these brands, creating a new emotional bond between the consumer and the company. The relationship between both is now founded on a new emotional primacy in contrast to the traditional promotion approach. 


\subsection{From Placement to Engagement}

Alongside this spiritual and emotional bondage, brands also ground their commercial strategy in an active and close relationship with the consumer. The use and development of technological platforms B2C (Business-to-Consumer) and $\mathrm{C} 2 \mathrm{C}$ (Consumer-to-Consumer) has been a commitment of tourism companies to attain this goal, changing the traditional paradigm of tourism distribution.

This is particularly relevant within the tourism services considering its immaterial and perishable dimensions. Inspired by the effects and action of $\mathrm{C} 2 \mathrm{C}$ platforms known as virtual travel communities (such as www.tripadvisor.com) tourism companies have started to join these communities or to develop their own online spaces and tools and have ultimately entered the universe of social media, especially through Facebook (McCarthy et al., 2010).

In the Accor group this is quite visible in the group's homepage where one can find direct reference to the partnership with the Virtual Travel Community (VTC) Tripadvisor (see Figure 2).

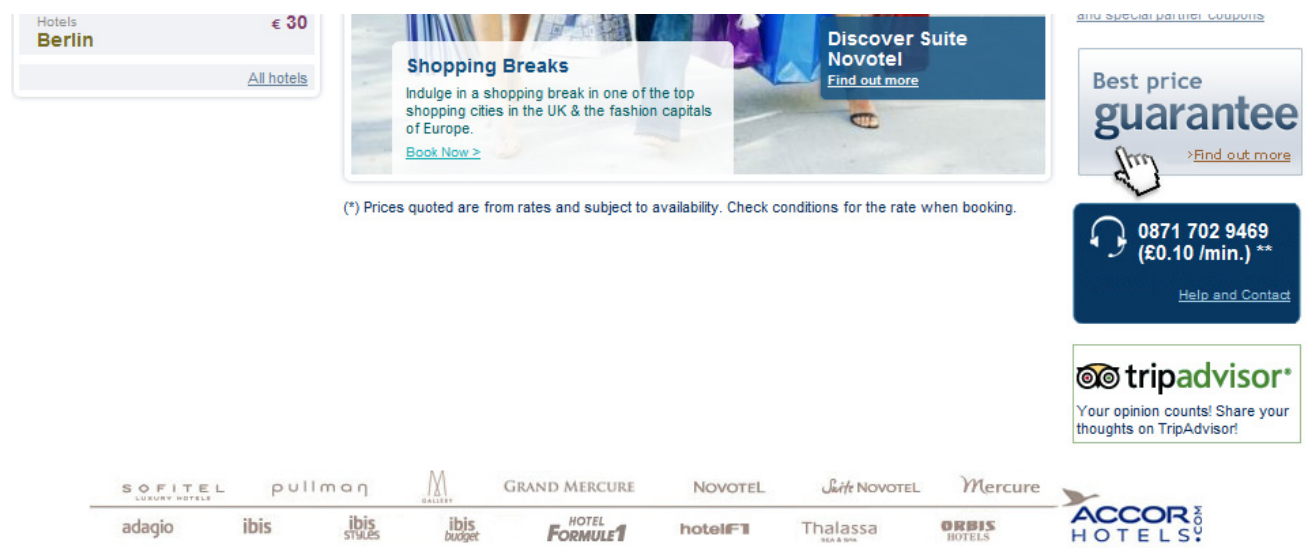

Figure 2. Accor and Tripadvisor - a partnership

Source: http://www.accorhotels.com/gb/united-kingdom/index.shtml

Instead of being interpreted as a threat (because consumers may publicly express all their feelings and thoughts about the company, whether about the companies' services or about any extraordinary situation - like for instance the strike of the TAP Portugal airline's pilots in Portugal in December 2011 and January 2012), they have been used as a strategic tool in the relationship with the consumer by ensuring a privileged and efficient means of communication and information management (for example in the management of crisis during strikes or natural disasters like the situation caused by the volcano in Iceland in 2010) basing the relationship between consumers and companies in a many-to-many principle (since communication may occur in various senses: consumer-company, company-consumer, consumer-consumer). And so the traditionally form of "word of mouth" has been reinvented and becomes even more powerful - electronic word of mouth (eWOM) (Sparkings \& Browning, 2011).

More recently, Emirates Airlines, in order to celebrate to have reached one million fans on Facebook, launched the following campaign:

"In celebration of reaching 1 million Facebook fans, we have given our A380 a bit of a makeover. The aircraft, with the Facebook sticker, will be flying around the world and we want you to send us your pictures of the plane when you spot it. Just private message us here or send an email to facebook@emirates.com and we'll feature your picture on this page. Thanks again to everyone who participated in helping us reach this milestone!" (November, 2012). 


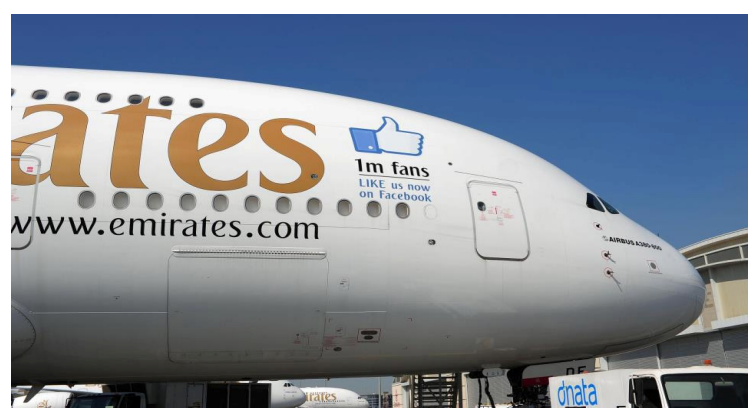

Figure 3. Facebook: a strategic tool of social media - the case of Emirates

Source: Emirate's Facebook

In this particular context and in operational terms, the company website, its Facebook profile or other similar tools become a space for sharing and communication between consumers - communitization .

"Technology not only connects and propels countries and companies toward globalization but also connects and propels consumers toward communitization. (...)Companies that want to embrace this new trend should accommodate this need and help consumers connect to one another in communities. Godin argued that succeeding in business requires the support of communities” (Kotler et al., 2010:33).

The distribution process moves into a more complex stage of engagement where there is a relationship and active participation of the consumer beyond the mere commercial transaction. Perhaps, the F-Commerce (Facebook-Commerce) can become the state-of-the-art this new stage:

"F-commerce for consumer brands is new and experimental, and future trends will depend on how successful f-commerce turns out to be at achieving brand objectives. The future off-commerce is not set; there is no fate but that which brands make for themselves" (Marsden, 2011:25).

\subsection{From Product to Experiences: Co-Creation \& Ancillary Revenue}

These new communication tools also contribute for the strategic marketing of tourism business since the information gathered is used as a vital source for innovation and development of tourism products. On the one hand they ensure a fundamental means for the products/services' tangibility, offering consumers the opportunity to share with each other their evaluation and opinion about the product in an independent way. On the other, they provide an information channel to the company to improve and customize its service based on the consumer himself - a process of co-creation.

"We observe three key processes of co-creation. First, companies should create what we call a "platform," which is a generic product that can be customized further. Secondly, let individual consumers within a network customize the platform to match their own unique identities. Finally, ask for consumer feedback and enrich the platform by incorporating all the customization efforts made by the network of consumers" (Kotler et al., 2011:33).

Based in this co-creation ideal tourism companies tend to transform their online communication platforms into real "virtual meeting points" that achieve a high level of credibility and unique image due to the level of use, relationship and interaction with the consumer. Evidence of this is the increasingly holistic and integrated nature of the tourism experience and the growing use of diagonal diversification strategies regardless of their position in the value chain (Poon, 1993). Consider the website of TAP Portugal (Winner of the award for best European airline in 2011). 


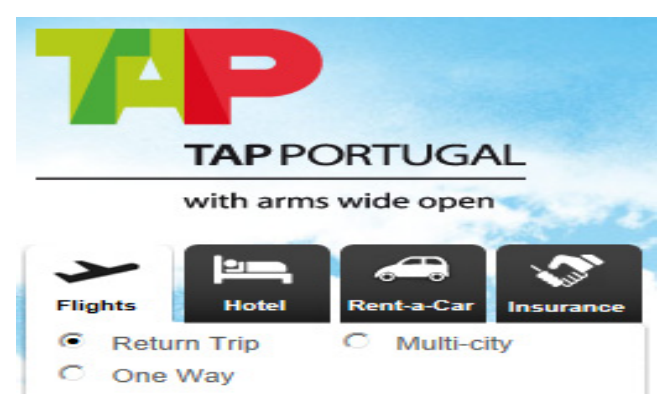

Figure 4. TAP Portugal - homepage - extract

Source: http://www.flytap.com/Portugal/pt/Homepage

Today this website is not just a mere tool to sell plane tickets online. The company has enhanced its online communication platform through strategic partnerships with other credible reference brands (like www.booking.com) that offer other tourism services and thus leading the consumer to associate TAP Portugal with values such as trustworthiness and reliability and allowing him/her to book a wide range of services (see Figure 4).

These services are presented to the consumer as part of the company's portfolio because they are relevant in the demand context and are an added value to the tourism experience. This diagonal diversification strategy has allowed TAP Portugal to achieve a leading position in the relationship with the consumer and allows him/her to build his/her own personal travel experience according to this/her specific needs. Instead of simply selling plane tickets, TAP Portugal allows its customers to idealize and customize their tourism experience in its website.

Given that it is based on the primacy of ancillary revenues this business model has also repercussions in the financial gains of the company (Tranter et al., 2009).

Instead of simply offering tourism products, tourism businesses use these new concepts and management tools in order to provide the consumer with the necessary means for the customization of their own personal tourism experience and therefore allowing him/her to actively engage in the development and innovation of the product and company.

\subsection{From Price to Exclusivity: Ancillary Revenue \& Yield Management}

The ancillary revenues business model gives a sense of exclusiveness to the client, allowing him/her to create his/her tourism experience according to his/her needs. However it also important to bear in mind the increasingly competitive, global and transparent nature of the tourism market which demands a more active and dynamic management of the "value for money" offered by businesses in this sector. Given this context, companies tend to emphasize and reinforce the Revenue \& Yield management philosophy and tools in their management models.

"The move towards new tourism stimulated by a more quality conscious and independent minded consumer and by the new technologies now being used to maximize yield rather than volume" (Knowles, et al., 2004:16).

This situation results from the fact that Revenue \& Yield management focuses on the management of demand rather than supply, in contrast to the previous management premises and tools used so far. Until now the management of tourism business was conditioned by the premise that supply was a perishable good, a fact that reached its height with the over use of the last minute sales. This management philosophy turned out to be inadequate because it entailed a set of limitations to the process and financial performance of tourism businesses, namely in the loss of benefits and inadequate cash flow which were insufficient to the business financial needs. For its part Yield \& Revenue management which is sustained in the BAR axiom (Best Available Rate) has demand and its dynamic nature as starting point for the management process. This philosophy allows not only a dynamic product/service relationship determined by demand but also stimulates the early booking philosophy (and all its inherent advantages of anticipation, either on the financial level or the operation management level) (Abrate et al., 2012).

It is also important to acknowledge the growing relevance of communication and sales online tools, either due to the new consumer profile or the tourism service's own nature that is increasingly global and more committed to the development of e-mobile solutions. This gives a unique set of transparency, accessibility and comparability to the marketing of tourism business that is translated into an added negotiating power given to the consumer. 
Therefore merely competing for price becomes extremely risky and vulnerable not only for the business players but also for the industry as a whole, given the potential price wars and succeeding dumping.

In such a context the price variable succumbs, giving place to the exclusiveness concept since the "value for money" must be primarily aligned with the consumers' unique needs and preferences.

\section{Conclusions and Guidelines for Future Research}

The current strategic options of tourism companies generally reflect the circumstances of a context that is increasingly global, interdependent, uncertain, technological and focused on sustainability issues.

The growing control of large multinational companies which are based on the primacy and potential of scale, scope and knowledge scales is increasingly significant. Therefore its impact and structural change in the market are also progressively significant and should be the object of further research.

Still regarding tourism market structure, the rapid emergence of low cost and its likely potential growth place it as an important segment whose features and changes it may cause in the balance of the market should also be taken into consideration. New business strategies related to unbundling philosophy and ancillary revenue should be considered and properly evaluated as well.

Tourism and its business activity are facing a scenario of change conditioned especially by the increase of demand, new values and premises like sustainability and social responsibility. For this reason a more thorough and varied approach to demand is needed, namely on the consumer behavior level. However this is not a standardized behavior and we are witnessing a counter-cycle in the developed markets in contrast with the emerging ones. There is a concentration of business translated in various mergers and acquisitions and the growth of the budget market. Nevertheless due to the diversification of the demand, companies tend to bet in brands as a priority form of supply, such as budget branded (in airline business, rent-a-car, ship cruises) and residence branded (high value for money).

The diversity of challenges introduced by the internet also needs special attention by virtue of changes it may produce in different dimensions of the business, either indirectly, by means of changing the consumer profile, or directly, in terms of new product concepts, new forms of marketing and management tools. In this new scenario the commercial action of tourism organizations tends to turn to a new pattern where promotion gives place to emotion, price to exclusivity, placement to engagement and product to experience.

If there are opportunities given the increase of the potential market, there are also challenges regarding a new heterogeneous, experienced and informed demand that must be considered. This is a reality that lacks monitoring given its present state of change and evolution. On the other hand, the growing implementation of diagonal diversification strategies reflects this scenario and reinforces the importance of research.

Finally it should be noted that the context identified and analyzed in this article refers to structural dimensions, so that the nature of the changes here in question are not completed processes. On the contrary, likewise the scope and purpose of approach of this article, we are facing a set of circumstances that should be understood as transformation vectors which due to their scope and structural nature should be studied and monitored using different realities and study-cases.

It is therefore important to conduct continuous and systematic studies that will ensure the validation of the trends described and discussed here, using different realities in terms of dimension, business models and processes as well as different geographical realities.

\section{References}

Abrate, G., Fraquelli, G., \& Viglia, G. (2012). Dynamic pricing strategies: Evidence from European hotels. International Journal of Hospitality Management, $31(1), \quad$ 160-168. http://dx.doi.org/10.1016/j.ijhm.2011.06.003

Accor. (2011). Registration Document and Annual Financial Report. Paris: Accor.

Airbus. (2012). Global Market Forecast 2012-2031: Navigating the Future. Blagnac: Airbus.

Canina, L., Kim, J., \& Ma, Q. (2010). What We Know About M\&A Success - a Research Agenda for Lodging Industry. Cornell Hospitality Quarterly, 51(1), 81-101. http://dx.doi.org/ 10.1177/1938965509354448

Doganis, R. (2001). The Airline Business in the $21^{\text {st }}$ Century. New York: Routledge.

Evans, N., Campbell, D., \& Stonehouse, G. (2006). Management for Travel and Tourism. Oxford: Butterworth-Heinemann. 
Holjevac, I. (2003). A vision of tourism and the hotel industry in the 21st century. International Journal of Hospitality Management, 22(2), 129-134. http://dx.doi.org/10.1016/S0278-4319(03)00021-5

Kang, K., Stein, L., Heo, C., \& Lee. (2012). Consumers' willingness to pay for green initiatives of the hotel industry. International Journal of Hospitality Management, 31(2), 546-572. http://dx.doi.org/10.1016/j.ijhm.2011.08.001

Knowles, T., Diamantis, D., \& El-Mourhab, J. (2004). The Globalization of Tourism and Hospitality. London: Thomson.

Kotler, P., Kartaya, H., \& Setiawan, I. (2010). Marketing 3.0 - From Products to Customers to the Human Spirit. New Jersey: John Wiley \& Sons, Inc.

Lancaster, C., \& Stillman, D. (2002). When Generations Collide: Who They Are. Why They Clash. How to Solve the Generational Puzzle at Work. New York: HarperCollins Publisher.

Lusensky, J. (2011). Sounds Like Branding: Use the Power of Music to Turn Customers into Fans. London: A \& C Black Publishers.

Mangold, W., \& Smith, K. (2012). Selling to Millennials with online reviews. Business Horizons, 55(2), 141-153. http://dx.doi.org/10.1016/j.bushor.2011.11.001

Marriott International Inc. (2012). Annual Report. Bethesda, Marriott International Inc.

Marsden, P. (2011). F-commerce; Selling on Facebook, The Opportunity for Consumer Brands. Syzygy White Paper. Retrieved Jun 12, 2012 from http://socialcommercetoday.com/documents/Syzygy_2011.pdf

McCarhty, L., Stock, D., \& Verma, R. (2010). How Travelers Use Online and Social Media Channels to Make Hotel-choice Decisions. Cornell Hospitality Report, $10(18), \quad$ 5-18. http://dx.doi.org/10.1177/1938965512445161

O'Neil, J., \& Carlbäck, M. (2011). Do brands matter? A comparison of branded and independent hotels' performance during a full economic cycle. International Journal of Hospitality Management, 30(3), 515-521. http://dx.doi.org/10.1016/j.jhm.2010.08.003

Poon, A. (1993). Tourism, Technology and Competitive Strategies. Wallingford: CABI.

Slattery, P. (2009). The Otus theory of hotel demand and supply. International Journal of Hospitality Management, 28(1), 113-120. http://dx.doi.org/10.1016/j.ijhm.2008.06.005

Sparks, B., \& Browning, V. (2011). The impact of online reviews on hotel booking intentions and perception of trust. Tourism Management, 32(6), 1310-1323. http://dx.doi.org/ 10.1016/j.tourman.2010.12.011

Taylor, G., \& Chesworth, N. (2005). Travel Styles. In Theobald, W. (Ed.), Global Tourism (pp. 294-308). London: Butterworth-Heinemann.

Tranter, K., Stuart-Hill, T., \& Parker, J. (2009). An Introduction to Revenue Management for the Hospitality Industry - Principles and Practices for the Real World. New Jersey: Pearson Education.

Tribe, J. (2010). Strategy for Tourism. Oxford: Goodfellow Publishers.

UNWTO [United Nations World Tourism Organization]. (2011). Tourism Towards 2030: Global Overview. Madrid: UNWTO.

UNWTO [United Nations World Tourism Organization]. (2013). International tourism to continue robust growth in 2013. Retrieved February 12, 2013 from http://media.unwto.org/en/press-release/2013-01-28/international-tourism-continue-robust-growth-2013

Weber, M., \& Dinwoodie, J. (2000). Fifth Freedoms and Airline Alliances. Journal of Air Transport Management, 6(1), 51-60. http://dx.doi.org/10.1016/S0969-6997(99)00022-8

Yeoman, I. (2008). Tomorrow's Tourist: Scenarios \& Trends. Oxford: Elsevier.

Yeoman, I., Rebecca, T., \& Mars, M. (2012). 2050: Tomorrow's Tourism. Bristol: Channelview.

Yip, G. (1992). Total Global Strategy: Managing for Worldwide Competitive Advantage. New Jersey: Prentice Hall. 


\section{Notes}

Note 1.

http://www.staralliance.com/assets/doc/en/about/member-airlines/pdf/star_alliance_factsfigures_01AUG11.pdf Note 2. http://pt.oneworld.com/news-information/oneworld-fact-sheets/oneworld-at-a-glance/

Note 3. http://static.skyteam.com/Global/Press/Facts\%20and\%20figures/Fact\%20Sheet.pdf

Note 4. Share Market | Source: IATA WATS 2007, $52^{\text {nd }}$ edition 